\title{
ANALISIS BAKTERI Salmonella sp. PADA DAGING AYAM POTONG YANG DIPASARKAN PADA PASAR TRADISIONAL DAN PASAR MODERN DI KOTA MEDAN
}

\author{
(Analysis of Bacteria Salmonella sp. on Broiler Meat in Traditional and \\ Modern Market in Medan)
}

\author{
Variam Fas Sabion Bakara', Ma'ruf Tafsin' ${ }^{2}$, Hasnudi $^{2}$ \\ 1. Mahasiswa Program Studi Peternakan Fakultas Pertanian Universitas SumateraUtara \\ 2. Staf Pengajar Program Studi Peternakan Fakultas Pertanian Universitas Sumatera Utara
}

\begin{abstract}
This study aims to determine the presence of bacterial contamination of Salmonella sp. and total microbial in broiler meat were sold at traditional markets and modern markets in Medan city. This study used a survey method with purposive sampling technique and used 60 samples (30 from the traditional markets and 30 from modern markets). This study was conducted in 5 traditional market (market center Medan, Sukaramai market, Sei Sikambing market, Pringgan market and market Simpang Limun) and 5 modern market (Carrefour, Hypermart, Giant, Lotte mart and Brastagi supermarket) and were analyzed at the Laboratory Center for Examiners Investigator Disease Region I Regional Veterinary Medan. The results showed an average total microbes in sample from traditional markets were $6.98 \mathrm{log}$ CFU/g and from the modern markets were $5.77 \mathrm{log}$ CFU/g. The number of samples were contaminated by Salmonella sp. on traditional markets were 0 from 30 samples, whereas on modern market were 2 of the 30 samples. The conclusion of this study is the average of total microbes in samples from traditional markets is higher than the modern market while the bacterial contamination rate of Salmonella sp. on traditional market were $0 \%$ and the modern market were $6.7 \%$.
\end{abstract}

Keywords: Broiler meat, Salmonella sp., total microbe, traditional market, modern market

\begin{abstract}
ABSTRAK
Penelitian ini bertujuan untuk mengetahui adanya cemaran bakteri Salmonella sp. dan total mikroba pada daging ayam potong yang dipasarkan pada pasar tradisional dan pasar modern di kota Medan. Penelitian ini menggunakan metode survei dengan teknik purposive sampling dengan jumlah sampel sebanyak 60 sampel (30 dari pasar tradisional dan 30 dari pasar modern). Penelitian ini dilaksanakan di 5 pasar tradisional (Pusat pasar Medan, pasar Sukaramai, pasar Sei Sikambing, pasar Simpang Limun dan pasar Pringgan) dan 5 pasar modern (Carefour, Hypermart, Giant, Lotte mart dan Brastagi supermarket) yang terdapat di kota Medan dan dilanjutkan dengan pengujian di Laboratorium Balai Penguji Penyidik Penyakit Veteriner Regional Wilayah I Medan. Hasil penelitian menunjukkan rata-rata total mikroba pada sampel yang berasal dari pasar tradisional sebesar 6,98 log CFU/g dan yang berasal dari pasar modern sebesar 5,77 log CFU/g. Tingkat cemaran bakteri Salmonella sp. yang berasal dari pasar tradisional adalah 0 dari 30 sampel sedangkan yang berasal dari pasar modern adalah 2 dari 30 sampel. Kesimpulan dari penelitian ini adalah rata-rata total mikroba pada sampel yang berasal dari pasar tradisional lebih tinggi dibandingkan pasar modern sedangkan untuk tingkat cemaran bakteri Salmonella sp. pada pasar tradisional adalah $0 \%$ dan pada pasar modern adalah $6,7 \%$.
\end{abstract}

Kata Kunci: Daging ayam potong, Salmonella sp., total mikroba, pasar tradisional, pasar modern 


\section{PENDAHULUAN}

Ayam dipelihara terutama untuk digunakan daging dan telurnya dan merupakan sumber penting protein hewani. Daging ayam merupakan bahan makanan yang mengandung gizi tinggi yaitu protein yang sangat tinggi khususnya bagian dada yaitu $23,3 \%$, kandungan air 74,4\%, lemak 1,2\%, dan abu sebesar 1,1\%, memiliki rasa dan aroma yang enak, tekstur yang lunak, serta harga yang relatif murah. Berdasarkan alasan tersebut, daging ayam lebih banyak diminati oleh masyarakat jika dibandingkan dengan daging sapi. Konsumsi daging ayam mencapai hingga 30\% dari konsumsi daging dunia. Berdasarkan survei Sosial Ekonomi Nasional, 2007 - 2013 diperoleh data konsumsi daging ayam ras pada tahun 2013 sebanyak 3,650 kg per kapita per tahun, artinya konsumsi daging ayam masyarakat memiliki cenderung meningkat setiap tahunnya dengan rata-rata pertumbuhan 4,60\%. Daging ayam dilaporkan sebagai salah satu bahan makanan yang banyak ditemui kontaminan bakteri patogen yaitu bakteri Salmonella sp. Bakteri Salmonella sp. yang mencemari daging ayam akan menimbulkan dampak yang merugikan bagi kesehatan yaitu dapat menyebabkan penyakit tifus, paratifus dan salmonellosis. Kontaminasi mikroba pada bahan pangan juga akan dapat menyebabkan kerusakan dan penurunan mutu bahan pangan.

Kontaminasi Salmonella sp. pada ayam dapat berasal dari peternakan yang terinfeksi. Selain itu, kejadian meningkatnya salmonellosis karena sistem pemotongan yang terdapat di pasar tradisional, dimana keadaan pasar yang terbuka dan tidak mempedulikan aspek kebersihan produk yang dijualnya (suhu ruang $27-30^{\circ} \mathrm{C}$ ). Pada pasar tradisional tersebut, mikroba patogen khususnya Salmonella sp. dapat tumbuh dengan subur karena Salmonella sp. dapat tumbuh optimal pada suhu $37^{\circ} \mathrm{C}$ dan juga dapat tumbuh pada suhu ruang (27-30 $\left.{ }^{\circ} \mathrm{C}\right)$. Penjualan daging ayam pada pasar swalayan diasumsikan lebih baik dibandingkan dengan pasar tradisional karena disajikan dalam keadaan tertutup dengan menggunakan pengemas atau showcase serta dijajakan dengan memperhatikan suhu rak pemajangan karkas (suhu $0-5^{0} \mathrm{C}$ ).

Pada tahun 2001, Balai Pengujian Mutu Produk Peternakan (BPMPP) Bogor, melakukan pengujian cemaran Salmonella sp. pada sampel daging ayam dan telur. Hasil pemeriksaan itu melaporkan bahwa 17 dari 347 sampel daging ayam $(4,9 \%)$ tercemar Salmonella sp., sedangkan pada telur (26 sampel) tidak ditemukan adanya cemaran. Laporan tersebut juga menyatakan bahwa 7 dari 42 sampel daging ayam $(16,67 \%)$ yang berasal dari Daerah Istimewa Yogyakarta mengandung Salmonella sp. 
Oleh karena itu, untuk mencegah infeksi Salmonella sp. pada bahan makanan, maka harus dilakukan deteksi dan isolasi untuk mengkontrol penyebab infeksi. Seperti diketahui bahwa syarat mutu karkas dan daging ayam dalam SNI 7388:2009 menyatakan bahwa produk pangan tidak diperbolehkan mengandung Salmonella sp., alasan dari dicanangkannya "zero tolerance" ini adalah karena Salmonella sp. merupakan bakteri patogen dan penyebab terjadinya food borne disease.

\section{. BAHAN DAN METODE PENELITIAN}

\section{Tempat dan Waktu Penelitian}

Penelitian telah dilaksanakan pada pasar tradisional dan pasar modern di kota Medan dan dilanjutkan dengan pemeriksaan di Laboratorium Balai Penguji Penyidik Penyakit Veteriner Regional Wilayah I J1. Jend. Gatot Subroto-Medan. Penelitian ini dilaksanakan pada bulan April sampai dengan Juni 2014.

\section{Bahan dan Alat Penelitian}

Bahan yang akan digunakan dalam penelitian ini adalah daging ayam segar bagian dada, paha kanan dan paha kiri sebanyak 30 sampel dari pasar tradisional dan 30 sampel dari pasar modern yang ada di kota Medan. Media-media yang digunakan untuk analisis Salmonella adalah Lactose Broth (LB) sebagai media pra pengkayaan, Tetrathionate Broth (TTB) dan iodin sebagai media pengkayaan selektif, Xylose Lysine Desoxycholate Agar (XLDA), PCA (Plate Count Agar) sebagai media pertumbuhan bakteri, Buffered Peptone Water (BPW) sebagai larutan pengencer, alkohol $70 \%$ sebagai desinfektan dan akuades steril untuk melarutkan berbagai macam media.

Alat yang akan digunakan dalam penelitian ini adalah cawan petri steril, autoclave, labu erlenmeyer, gelas ukur, kapas, inkubator $37{ }^{\circ} \mathrm{C}$, lampu bunsen, pipet steril, tabung reaksi, oven, cool box, stomacher, vorteks, mikropipet dan tipnya, neraca analitik, tabung reaksi dan raknya, bunsen, jarum ose mata bulat dan lurus, plastik tahan panas steril, gunting dan pinset steril, aluminium foil, biosafety cabinet, colony counter, sarung tangan, jarum spuit $3 \mathrm{ml}$ dan $10 \mathrm{ml}$, masker, jas lab dan marker permanent.

\section{Metode Penelitian}

Penelitian ini merupakan penelitian survei yaitu untuk mengetahui adanya bakteri Salmonella sp. pada daging ayam potong yang dipasarkan pada pasar tradisional dan pasar 
modern di kota Medan dengan melakukan pemeriksaan Laboratorium. Informasi tentang kondisi ayam potong yang berada di tempat penjualan diperoleh dengan melakukan pengamatan langsung pada saat pengambilan sampel. Data yang dikumpulkan dalam penelitian ini adalah informasi yang dapat dilihat secara langsung yaitu kebersihan tempat penjualan, kebersihan dari peralatan yang digunakan, kondisi penjual/penjamah secara umum dan lingkungan sekitar tempat penjualan.

\section{Analisis Data}

Data disajikan dalam bentuk tabel distribusi frekuensi, untuk melihat adanya bakteri Salmonella sp. yang terdapat pada daging ayam potong dan dilanjutkan dengan uji Chi Kuadrat $\left(\chi^{2}\right)$. Uji Chi Kuadrat dihadapkan pada suatu pengujian apakah perbedaan antara frekuensi hasil observasi dengan frekuensi yang diharapkan dari sampel yang terbatas merupakan perbedaan yang signifikan atau tidak (Siregar, 2010).

Dengan model linier :

$$
\chi^{2}=\left(\frac{\sum(f o-f e)^{2}}{f e}\right)
$$

Keterangan :

$\chi^{2}=$ Nilai Chi Kuadrat

$f_{o}=$ Frekuensi cemaran salmonella sp. pada pasar tradisional

$f e=$ Frekuensi cemaran salmonella $\mathrm{sp}$. pada pasar modern

Kaidah Keputusan:

- $\quad$ Jika $\chi^{2}$ hitung $\leq \chi^{2}$ tabel, maka Ho diterima

- Jika $\chi^{2}$ hitung $\geq \chi^{2}$ tabel, maka Ho ditolak

Sementara itu, untuk melihat perbedaan total mikroba yang terdapat pada daging ayam potong dan dilanjutkan dengan uji testt $(\mathrm{t})$. Uji t merupakan uji beda untuk mengetahui adakah perbedaan mean atau rerata yang bermakna antara 2 kelompok bebas yang berskala data interval/rasio.

Dengan model linier :

$$
\mathrm{t}: \frac{\overline{\mathrm{X}}_{-}-\overline{\mathrm{X}}_{2}}{\mathrm{~S}_{\mathrm{X}} \overline{\overline{\mathrm{X}}}}
$$

Keterangan :

$$
\begin{array}{ll}
\mathrm{t} & : \text { Nilai t hitung } \\
\overline{\mathrm{X}}_{1} & \text { : Rata-rata kelompok } 1
\end{array}
$$


$\overline{\mathrm{X}}_{2} \quad$ : Rata-rata kelompok 2

$S \overline{\mathrm{X}} \quad \overline{\mathrm{X}} \quad$ Standard error kedua kelompok

Kaidah Keputusan:

- Jika t-hitung > t-tabel : Berbeda secarasignifikan (Ho ditolak)

- Jika t-hitung < t-tabel: Tidak berbeda secarasignifikan (Ho diterima)

\section{Pelaksanaan Penelitian}

\section{Pengambilan Sampel}

Sebelum pengambilan sampel, terlebih dahulu dipersiapkan alat-alat yang akan digunakan seperti plastik putih bersih, kertas label dan pulpen. Sampel diambil dari lima pasar tradisional (A1, A2, A3, A4 dan A5) dan lima pasar modern (B1, B2, B3, B4 dan B5) di kota Medan. Setiap sampel yang diambil dimasukkan ke dalam plastik putih bersih, selanjutnya plastik diberi kode, lokasi pengambilan dan tanggal pengambilan sampel dengan menggunakan pulpen kemudian dimasukkan ke dalam cool box dan dibawa ke laboratorium untuk dilakukan pemeriksaan.

Pengambilan sampel daging ayam potong di pasar tradisional dilaksanakan pada pukul 08.00 WIB dan di pasar modern pada pukul 10.00 WIB. Pada pasar tradisional sampel diambil dari tiga orang pedagang. Sampel diambil sebanyak tiga sampel dari masing-masing pasar tradisional dan pasar modern, dimana bagian sampel yang diambil adalah bagian dada, paha kanan dan paha kiri. Sampel diambil sebanyak dua kali dengan waktu yang berbeda, sehingga total sampel yang dianalisis adalah 60 sampel.

\section{Pemeriksaan Sampel untuk Uji Total Plate Count}

Analisis total mikroba dilakukan dengan menimbang 25 gram sampel secara aseptis dan dimasukkan kedalam kantong steril dan ditambahkan dengan $225 \mathrm{ml}$ larutan BPW kemudian di stomacher selama 2 menit. Selanjutnya tuangkan larutan BPW sebanyak $9 \mathrm{ml}$ kedalam tabung reaksi steril dan kemudian ditambahkan $1 \mathrm{ml}$ suspensi pengenceran $10^{-1}$ dengan pipet steril ke dalam larutan $9 \mathrm{ml}$ BPW untuk mendapatkan pengenceran $10^{-2}$. Lakukan pengenceran $10^{-3}, 10^{-4}, 10^{-5}$ dan $10^{-6}$ dengan cara yang sama. Kemudian $1 \mathrm{ml}$ suspensi dari setiap pengenceran dimasukkan ke dalam cawan petri steril. Tuangkan media PCA yang sudah di dinginkan hingga suhu $45^{\circ} \mathrm{C}$ kedalam cawan petri yang telah berisi suspensi dan digerakkan secara hati-hati untuk menyebarkan sel-sel mikroba secara merata, yaitu dengan gerakan seperti angka delapan. Setelah agar membeku, cawan diinkubasi 
dengan posisi terbalik pada suhu $37^{\circ} \mathrm{C}$ selama $24 \pm 2$ jam. Setelah di inkubasi dihitung jumlah koloni yang tumbuh dengan menggunakan colony counter (BSN, 2008).

\section{Pemeriksaan Sampel untuk Uji Salmonella sp. (BSN, 2008)}

\section{Pre Enrichment (Pra Pengkayaan)}

Sebanyak 25 gram sampel ditimbang dan dimasukkan ke dalam kantung plastik steril. Kemudian ditambahkan $225 \mathrm{ml}$ Lactose Broth steril dan dihancurkan dengan menggunakan stomacher selama 120 detik. Sampel yang telah dihancurkan diinkubasi selama $24 \pm 2$ jam pada suhu $36 \pm 1^{\circ} \mathrm{C}$.

\section{Selective Enrichment (Pengkayaan Selektif)}

Sebanyak $1 \mathrm{ml}$ sampel dari Lactose Broth yang telah diinkubasi diinokulasikan ke dalam $10 \mathrm{ml}$ Tetrathionate Broth (TTB) yang telah dituang ke dalam tabung reaksi steril dan ditambahkan sebanyak $20 \mu$ iodin, kemudian diinkubasi pada suhu $36 \pm 1{ }^{\circ} \mathrm{C}$ selama $24 \pm 2$ jam.

\section{Isolasi Salmonella dengan Media Agar Selektif}

Sampel yang telah diinkubasi pada masing-masing media pengkayaan selektif diambil satu ose dan digoreskan secara kuadran pada media Xylose Lysine Desoxycholate Agar (XLDA), kemudian diinkubasi pada suhu $36 \pm 1{ }^{\circ} \mathrm{C}$ selama $24 \pm 2$ jam dengan posisi terbalik. Setelah inkubasi, dilihat apakah ada koloni tipikal yang tumbuh pada media agar. Ciri-ciri koloni tipikal Salmonella pada media XLDA, koloni berwarna merah muda dengan atau tanpa warna hitam di tengahnya, beberapa akan tampak sebagai koloni yang besar, berwarna hitam mengkilap di tengahnya atau tampak sebagai koloni yang semuanya berwarna hitam.

\section{HASIL DAN PEMBAHASAN}

Gambaran umum lokasi pasar yang dijadikan sebagai tempat dilaksanakannya penelitian berdasarkan hasil pengamatan di lapangan dapat dilihat pada Tabel 1 di bawah ini.

\section{Gambaran Umum Lokasi Pasar Penelitian}

Berdasarkan Tabel 1 dapat dilihat bahwa terdapat perbedaan yang mendasar dari pasar tradisional dan pasar modern. Berdasarkan hasil pengamatan dapat dilihat bahwa kebersihan kondisi penjualan pada pasar modern lebih baik dibandingkan dengan pasar tradisional. Penjual di pasar modern sudah menggunakan celemek dan sudah menggunakan sarung tangan. Berdasarkan hasil observasi, daging ayam di pasar tradisional dipotong menjadi beberapa bagian dan bertumpuk dengan daging ayam lain serta jeroan. Sementara 
pada pasar modern daging ayam sudah dimasukkan ke dalam kemasan ayam potong berupa styrofoam dan pada kemasan dapat dilihat tanggal pengemasan dan tanggal kadaluarsa yang rata-rata memiliki rentang waktu 3 hari antara tanggal pengemasan dan tanggal kadaluarsa, kemudian disimpan dalam suhu dingin dan kondisinya bersih.

Tabel 1. Pengamatan deskriptif tentang lokasi pengambilan data di lapangan

\begin{tabular}{|c|c|c|}
\hline \multirow[t]{2}{*}{ Variabel } & \multicolumn{2}{|c|}{ JenisPasar } \\
\hline & Pasar Tradisional & Pasar Modern \\
\hline Tempat penjulan & Kotor dan basah & Bersih dan tersusun rapi \\
\hline Pembersihan bulu & $\begin{array}{l}\text { Ayam dicelupkan kedalam drum } \\
\text { yang berisi air panas }\left( \pm 52^{\circ}-60^{\circ} \mathrm{C}\right) \text {, } \\
\text { kemudian bulu dicabut, jeroan } \\
\text { dikeluarkan dan karkas dicuci } \\
\text { dengan air yang ditampung dalam } \\
\text { drum dan karkas diletakkan di meja } \\
\text { penjualan }\end{array}$ & $\begin{array}{l}\text { Ayam dicelupkan kedalam } \\
\text { air panas temperatur } 52^{\circ}- \\
60^{\circ} \mathrm{C} \text { selama } 3-5 \text { menit, } \\
\text { kemudian bulu dicabut, } \\
\text { jeroan dikeluarkan dan } \\
\text { karkas ayam dicuci dengan } \\
\text { air yang mengalir dan } \\
\text { karkas didinginkan dengan } \\
\text { temperatur } 0-5^{\circ} \mathrm{C}\end{array}$ \\
\hline Penyimpanan & & \\
\hline - Temperatur & $28-32^{0} \mathrm{C}$ & $0-5^{0} \mathrm{C}$ \\
\hline - Kondisiayam & Terbuka dan tergeletak di atas meja & $\begin{array}{l}\text { Tertutup dan dimasukkan } \\
\text { dalam freezer }\end{array}$ \\
\hline - Kemasan & Plastik kresek & Plastik dan Styrofoam \\
\hline Alas pemotongan & Talenan kayu & Talenanp lastik \\
\hline Kondisi penjual & $\begin{array}{l}\text { Tidak memakai celemek dan sarung } \\
\text { tangan }\end{array}$ & $\begin{array}{l}\text { Memakai celemek } \\
\text { sarung tangan }\end{array}$ \\
\hline
\end{tabular}

\section{Pengambilan Sampel}

Sampel daging ayam potong yang digunakan pada penelitian ini berasal dari 5 pasar tradisional dan 5 pasar modern di kota Medan dengan total sampel sebanyak 60 sampel. Kondisi sampel dari pasar tradisional maupun pasar modern dapat dilihat pada Tabel 2 berikut.

Tabel 2. Kondisi sampel daging ayam potong di pasar tradisional dan pasar modern di kota Medan

\begin{tabular}{|c|c|c|c|c|}
\hline Asal Sampel & Jenis Daging & $\begin{array}{l}\text { Jumlah } \\
\text { Sampel }\end{array}$ & $\begin{array}{l}\text { Kondisi } \\
\text { Sampel }\end{array}$ & Suhu Pe \\
\hline $\begin{array}{l}\text { Pasar Tradisional Medan } \\
\text { Pasar Modern }\end{array}$ & $\begin{array}{l}\text { Daging Potong } \\
\text { Daging Potong }\end{array}$ & $\begin{array}{l}30 \\
30\end{array}$ & $\begin{array}{l}\text { Segar } \\
\text { Segar }\end{array}$ & $\begin{array}{l}\text { Suhu kamar }\left(28-32^{\circ} \mathrm{C}\right) \\
\text { Suhu dingin }\left(0-5^{\circ} \mathrm{C}\right)\end{array}$ \\
\hline
\end{tabular}

Daging ayam potong segar dari pasar tradisional diambil dalam bentuk potongan daging segar yang terdiri dari potongan daging yang memiliki perdagingan yang banyak yaitu bagian paha kanan, paha kiri dan bagian dada. Sampel yang telah diambil dimasukkan ke 
dalam kantongan plastik putih steril untuk mencegah bertambahnya kontaminasi. Pada pasar modern, sampel diambil dalam kondisi telah dikemas dalam styrofoam dan ditutup dengan wrapping plastic. Daging ayam potong tersebut disimpan pada suhu dingin dengan menggunakan refrigerator/chiller sehingga daging ayam potong lebih awet.

\section{Analisis Total Mikroba}

Hasil analisis total mikroba pada sampel daging ayam potong yang dipasarkan pada pasar tradisional dan pasar modern di kota Medan dapat dilihat pada Tabel 3 berikut.

Tabel 3. Jumlah total mikroba (log CFU/g) pada pasar tradisional dan pasar modern di kota Medan

\begin{tabular}{|c|c|c|c|}
\hline \multirow[t]{2}{*}{ Kode Pasar } & \multirow[t]{2}{*}{ No sampel } & \multicolumn{2}{|c|}{ Nilai log CFU/g } \\
\hline & & Pasar Tradisional & Pasar Modern \\
\hline \multirow[t]{6}{*}{1} & 1 & 6,95 & 5,96 \\
\hline & 2 & 7,18 & 5,53 \\
\hline & 3 & 7,20 & 6,61 \\
\hline & 4 & 7,62 & 5,98 \\
\hline & 5 & 6,65 & 5,74 \\
\hline & 6 & 6,81 & 5,89 \\
\hline \multirow[t]{6}{*}{2} & 7 & 6,58 & 5,56 \\
\hline & 8 & 6,88 & 4,52 \\
\hline & 9 & 7,79 & 5,81 \\
\hline & 10 & 7,86 & 5,58 \\
\hline & 11 & 6,72 & 5,65 \\
\hline & 12 & 6,67 & 5,80 \\
\hline \multirow[t]{6}{*}{3} & 13 & 6,51 & 5,93 \\
\hline & 14 & 7,76 & 5,83 \\
\hline & 15 & 7,04 & 5,95 \\
\hline & 16 & 7,53 & 5,99 \\
\hline & 17 & 6,62 & 5,90 \\
\hline & 18 & 7,52 & 5,71 \\
\hline \multirow[t]{6}{*}{4} & 19 & 6,49 & 6,62 \\
\hline & 20 & 6,68 & 5,56 \\
\hline & 21 & 6,85 & 5,46 \\
\hline & 22 & 7,49 & 5,48 \\
\hline & 23 & 6,65 & 5,95 \\
\hline & 24 & 6,63 & 5,90 \\
\hline \multirow[t]{6}{*}{5} & 25 & 6,85 & 5,72 \\
\hline & 26 & 7,71 & 5,70 \\
\hline & 27 & 5,43 & 5,96 \\
\hline & 28 & 7,69 & 5,58 \\
\hline & 29 & 5,38 & 5,54 \\
\hline & 30 & 7,62 & 5,65 \\
\hline Rata-Rata* & & 6,98 & 5,77 \\
\hline
\end{tabular}

Keterangan $: *=$ nilait hitung $>\mathrm{t}$ tabel berbeda secara signifikan (Ho ditolak) atau signifikan pada probabilitas $0,05(\mathrm{P}<0,05)$ 
Berdasarkan Tabel 3 dapat dilihat total mikroba tertinggi terdapat pada pasar tradisional dengan rata-rata total mikroba sebesar 6,98 log CFU/g. Tingginya total mikroba yang terdapat pada sampel daging ayam potong pada pasar tradisional lainnya disebabkan oleh penanganan yang kurang higienis, kondisi daging yang diletakkan bertumpuk dengan daging yang lainnya, kondisi penyimpanan tanpa pendinginan dan berada di tempat udara terbuka sehingga hal tersebut dapat mengkondisikan pertumbuhan mikroba pada daging ayam potong baik mikroba pembusuk maupun patogen. Hal ini sesuai dengan pernyataan Purnawijayanti (2001), yang menyatakan bahwa penjualan daging ayam dipasar tradisional pada umumnya dilakukan dalam keadaan terbuka.

Standar TPC (Total Plate Count) maksimal untuk daging ayam segar berdasarkan SNI 3924:2009 adalah 1 x $10^{6} \mathrm{CFU} / \mathrm{g}$ atau 6,00 sehingga berdasarkan hasil analisis dari Tabel 3 diperoleh bahwa dari 30 sampel daging ayam potong dari pasar tradisional yang dianalisis hanya terdapat 2 sampel yang memiliki total mikroba yang sesuai dengan SNI yang telah ditetapkan yaitu terdapat pada pasar 5 dengan total mikroba 5,43 log CFU/g dan 5,38 $\log$ $\mathrm{CFU} / \mathrm{g}$ dan rata-rata total mikroba pada sampel yang berasal dari pasar modern sebesar 5,77 $\log$ CFU/g. Hasil analisis dari 30 sampel hanya terdapat 2 sampel yang tidak memenuhi SNI yang telah ditetapkan dan 28 sampel daging ayam potong lainnya sudah memenuhi standar yang telah ditetapkan. Hal ini jauh berbeda dengan hasil analisis total mikroba pada pasar tradisional. Oleh karena itu, perlu diketahui mutu mikrobiologi suatu produk pangan untuk melihat tingkat cemaran mikroba pada produk pangan tersebut, sehingga dapat diketahui resiko keamanannya apabila dikonsumsi (Ruslan, 2003).

Berdasarkan hasil uji t diperoleh bahwa nilai total mikroba pada pasar tradisional lebih tinggi dari nilai total mikroba pada pasar modern sehingga dapat disimpulkan bahwa terdapat perbedaan yang signifikan antara rata-rata total mikroba pada sampel daging ayam potong yang dijual di pasar tradisional dan pasar modern di kota Medan $(\mathrm{p}<0,05)$. Rata-rata untuk pasar tradisional adalah 6,98 dan rata-rata untuk pasar modern adalah 5,77. Secara keseluruhan dapat dilihat perbedaan diantara pasar tradisional dan pasar modern dari segi kebersihan lokasi maupun penjamah/penjual. Hal ini sesuai dengan pernyataan Gustiani (2009), bahwa pencemaran daging oleh mikroba dapat terjadi sebelum dan setelah hewan dipotong. Sumber pencemaran tersebut antara lain adalah: 1) hewan (kulit, kuku, isi jeroan), 2) pekerja/manusia yang mencemari produk ternak, 3) peralatan (pisau, alatpotong/talenan, pisau, boks), 4) bangunan (lantai), 5) lingkungan (udara, air, tanah) dan 6) kemasan. 
Menurut Purnomo dan Adiono (2007), terdapat faktor-faktor yang mempengaruhi pertumbuhan mikroorganisme dalam bahan pangan. Faktor-faktor tersebut adalah faktor intrinsik dan faktor ekstrinsik. Faktor intrinsik meliputi ketersediaan nutrisi (zat gizi), nilai $\mathrm{pH}$, aktivitas air $\left(\mathrm{a}_{\mathrm{w}}\right)$ yang terdapat dalam daging, potensi oksidasi-reduksi, faktor-faktor pengolahan dan ada tidaknya substansi penghambat pertumbuhan mikroorganisme. Sedangkan faktor ekstrinsik meliputi suhu penyimpanan, kelembaban, kondisi permukaan bahan pangan yang berhubungan dengan udara dan pengemasan bahan pangan.

\section{Hasil Pemeriksaan Bakteri Salmonella sp. Pada Sampel Daging Ayam Potong pada Pasar Tradisional dan Pasar Modern}

Penelitian ini dilakukan dengan pemeriksaan Salmonella sp.untuk mengetahui ada tidaknya Salmonella sp. pada daging ayam potong yang dipasarkan pada pasar tradisional dan pasar modern di kota Medan. Pemeriksaan ini berdasarkan syarat yang telah ditetapkan pada SNI 3924 : 2009 ditetapkan bahwa pada daging ayam potong segar tidak boleh mengandung Salmonella (negatif/ 25 gram).

Hasil pemeriksaan bakteri Salmonella sp terhadap 30 sampel daging ayam potong pada pasar tradisional dan 30 sampel daging ayam potong pada pasar modern dapat dilihat pada Tabel 4 berikut.

Tabel 4. Distribusi frekuensi hasil pemeriksaan bakteri Salmonella sp. pada daging ayam potong pada pasar tradisional dan pasar modern

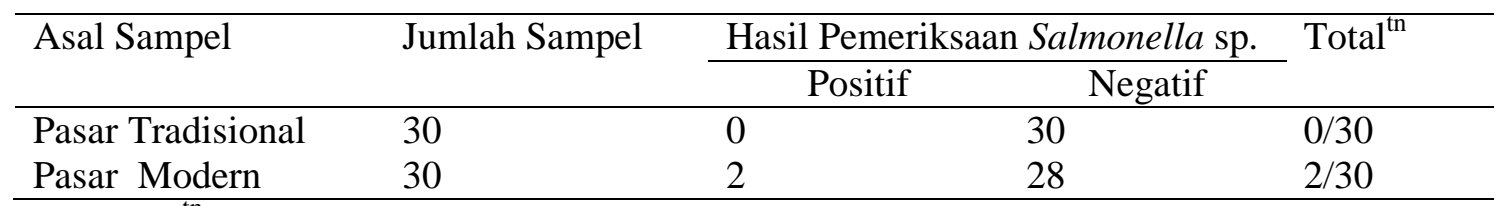

Keterangan $:^{\text {tn }}=$ hasil uji chi kuadrat tidak berbeda secara signifikan

Hasil analisis berdasarkan Tabel 4 dapat diketahui bahwa hasil pemeriksaan terhadap 30 sampel daging ayam potong pada pasar tradisional seluruh sampel tidak terdapat bakteri Salmonella sp. sehingga seluruh daging yang berasal dari pasar tradisional tersebut memenuhi syarat yang ditetapkan oleh SNI 7388:2009 yang menyatakan bahwa produk pangan tidak diperbolehkan mengandung Salmonella sp. hal ini dapat disebabkan karena kondisi yang tidak mendukung pertumbuhan bakteri Salmonella sp. pada daging dan adanya cemaran bakteri lain. Sementara itu, hasil analisis dari 30 sampel yang berasal dari pasar modern terdapat 2 sampel (6,7\%) positif tercemar bakteri Salmonella sp. meskipun penerapan sanitasi dan higiene pasar modern lebih baik daripada pasar tradisional. 
Padahal pada pasar modern penyimpanan daging dilakukan pada suhu dingin. Pendinginan dapat menghambat kerusakan bahan pangan, salah satunya dengan cara menghambat aktivitas mikroorganisme sehingga pertumbuhan mikroba akan terhenti (Herbert dan Sutherland, 2000).

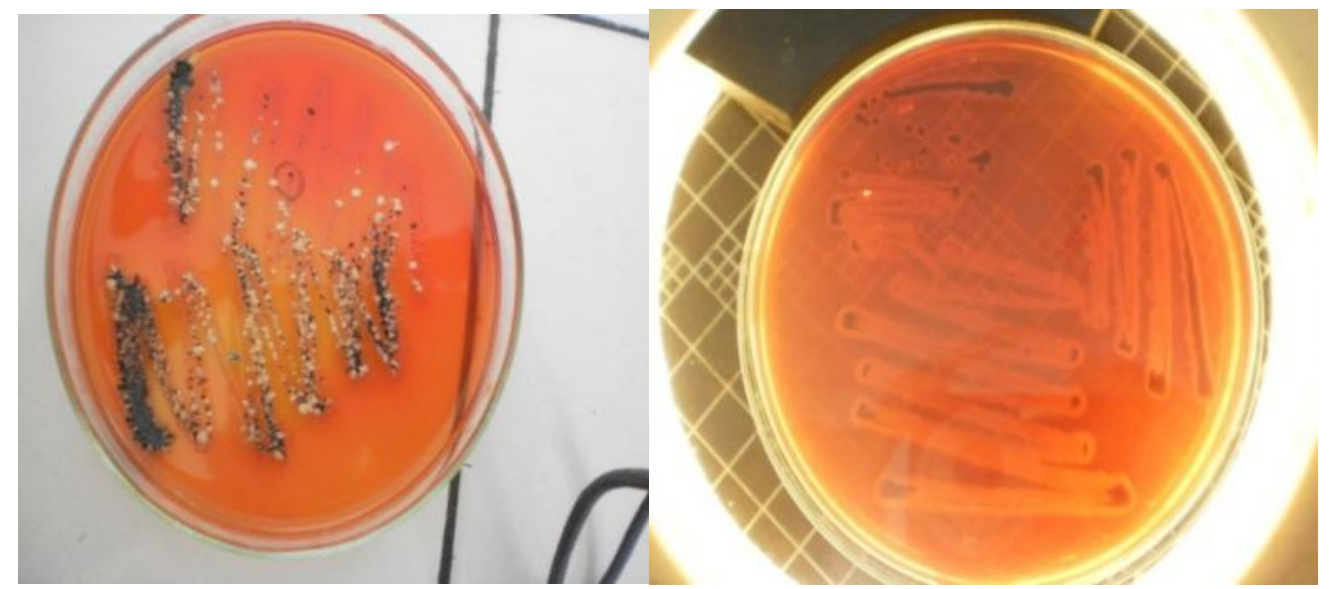

Gambar 1. Koloni bakteri Salmonella sp. pada media XLDA

Berdasarkan hasil penelitian Saptarini (2009), diperoleh tingkat isolasi Salmonella sp. dari 30 sampel daging sapi yang dianalisis diperoleh sebesar 16,67\%. Persentase terbesar terdapat pada supermarket yaitu dari 20 sampel terdapat 4 sampel (20\%) positif sedangkan pada pasar tradisional diperoleh 1 dari 10 sampel (10\%) positif mengandung Salmonella sp. Angka isolasi ini jauh lebih rendah dibandingkan dengan isolasi Salmonella sp. pada sampel daging ayam yang dilakukan oleh Sylviana (2008), diperoleh persentase sebesar 55\% yaitu dari pasar tradisional sebanyak 17 dari 40 sampel (42,5\%) sedangkan dari supermarket diperoleh 5 dari 40 sampel (12,5\%). Ada tidaknya bakteri Salmonella pada suatu produk pangan dapat disebabkan oleh beberapa faktor, antara lain adalah kondisi yang tidak mendukung untuk pertumbuhan bakteri Salmonella dan adanya cemaran bakteri lain seperti bakteri pembusuk dan bakteri asam laktat yang dapat menghambat pertumbuhan Salmonella sp., karena bakteri Salmonella sp. tidak dapat berkompetisi secara baik dengan bakteri-bakteri yang umum terdapat di dalam bahan makanan.

Berdasarkan hasil uji Chi kuadrat, diperoleh nilai $\chi^{2}$ hitung $\leq \chi^{2}$ tabel dan tingkat isolasi Salmonella sp. pada sampel daging ayam potong yang berasal dari pasar tradisional adalah sebesar 0\% sementara tingkat isolasi Salmonella sp. pada sampel daging ayam potong yang berasal dari pasar modern adalah sebesar 6,7\%, sehingga dapat disimpulkan bahwa frekuensi hasil observasi dengan frekuensi yang diharapkan dari sampel pada pasar tradisional dan pasar modern merupakan perbedaan yang tidak signifikan. Oleh karena itu, 
dari hasil penelitian dapat disimpulkan bahwa meskipun higiene sanitasi di pasar modern lebih baik dari pasar tradisional, namun tidak menutup kemungkinan bahwa sampel daging ayam potong di pasar modern terbebas dari bakteri Salmonella sp. Hal ini dapat juga terjadi karena pada pasar modern juga belum bisa mendukung ayam terbebas dari mikroba. Cemaran mikroba pada produk unggas juga dapat disebabkan dari tempat peternakan dimana terdapatnya kotoran ternak yang telah tertular oleh Salmonella yang mencemari tempat pakan maupun tempat minum ternak, sehingga masuk dan berkembang biak di dalam saluran pencernaan unggas. Hal lain yang mungkin dapat terjadi yaitu pada saat pemotongan dan pengemasan melalui pisau ataupun alat-alat lainnya, sehingga keadaan karkas yang tercemar oleh bakteri Salmonella lebih banyak sesudah proses penyembelihan daripada sebelumnya. Oleh karena itu, adanya temuan bakteri Salmonella sp. pada daging ayam potong di pasar modern tersebut menunjukkan bahwa mikroorganisme patogen juga bisa hidup dalam suhu rendah sebelum pembusukan terjadi.

\section{KESIMPULAN}

Rata-rata total mikroba pada sampel daging ayam potong yang berasal dari pasar tradisional lebih tinggi dibandingkan sampel dari pasar modern di kota Medan, sedangkan tingkat cemaran bakteri Salmonella sp. pada sampel daging ayam potong yang berasal dari pasar tradisional adalah $0 \%$ dan yang berasal dari pasar modern adalah $6,7 \%$.

\section{DAFTAR PUSTAKA}

Balai Pengujian Mutu Produk Peternakan (BPMPP). 2001. Lokakarya Nasional Keamanan Pangan Produk Peternakan, Bogor.

Badan Standardisasi Nasional. 2008. SNI 2897:2008 tentang Metode Pengujian Cemaran Mikroba dalam Daging, Telur dan Susu, serta Hasil Olahannya. Departemen Pertanian, Jakarta.

2009. SNI 01-3924-2009 tentang Mutu Karkas dan Daging Ayam Pedaging. Departemen Pertanian, Jakarta.

2009. SNI 7388:2009 tentang Batas maksimum cemaran mikroba dalam pangan. Departemen Pertanian, Jakarta.

Gustiani, E. 2009. Pengendalian Cemaran Mikroba pada Bahan Pangan Asal Ternak (Daging dan Susu) Mulai dari Peternakan Sampai Dihidangkan. Jurnal Litbang Pertanian. Vol.28 (3) : 96-100 
Herbert, R. A. dan J. P. Sutherland. 2000. Di dalam : Lund, B.M., T.C. Baird-parker,dan G.W.Gould, , 2000. The Microbiological Safety and Quality of Food. Vol. I. Aspen Publishers, Inc., Gaitehersburg, Maryland.

Purnawijayanti. 2001. Penelitian Penanganan pada Daging. Universitas Negeri Malang, Malang.

Purnomo, H dan Adiono. 2007. Ilmu Pangan. Universitas Indonesia, Jakarta.

Ruslan. 2003. Keamanan Mikrobiologi dan Survei Lapang Sayuran Olahan di Daerah Bogor Barat. Skripsi. Fakultas Teknologi Pertanian. Institut Pertanian Bogor, Bogor.

Saptarini, K. 2009. Isolasi Salmonella spp. pada Sampel Daging Sapi di Wilayah Bogor serta Uji Ketahanannya terhadap Proses Pendinginan dan Pembekuan. Skripsi. Fakultas Teknologi Pertanian. Institut Pertanian Bogor, Bogor.

Survei Sosial Ekonomi Nasional, 2007 - 2013. Konsumsi Rata-rata per Kapita Setahun Beberapa Bahan Makanan di Indonesia. http://www.pertanian.go.id/indikator/tabe15b-konsumsi-rata, diakses tanggal 06 Maret 2014.

Sylviana. 2008. Prevalensi Cemaran Salmonella Typhimurium Pada Potongan Karkas Ayam dan Efektivitas Ekstrak Daun Sirih (Piper betle, Linn.) Sebagai Larutan Sanitaiser Alami. Tesis. Sekolah Pasca Sarjana, Institut Pertanian Bogor, Bogor. 